\title{
Electron Microscopic Observations on Growing and Dividing Protoplasts of Bacillus megaterium
}

\author{
By I. KUSAKA \\ Institute of Applied Microbiology, The University of Tokyo, Tokyo, Japan
}

(Accepted for publication 3 July 1970)

SUMMARY

Protoplasts of Bacillus megaterium grew well and divided in I \% casein hydrolysate (enzymic) medium containing $0.5 \mathrm{M}-\mathrm{NaCl}$ as the stabilizer. A fibrous layer of coat, possibly composed of murein, developed around the growing protoplast. A small protuberance then formed on the protoplast and grew until a symmetrical dumbbell-shaped body was formed. The coat did not develop around the 'daughter' protoplast.

Division was completely inhibited in the presence of penicillin, and a coat did not develop around the protoplast. Materials which might otherwise have formed the coat in the absence of penicillin were released into the medium.

After $12 \mathrm{~h}$. of growth in the absence of penicillin, normal cell wall was formed around the cell, although reversion to bacillary form was not observed. The cells divided into 4 to 6 cells simultaneously by transverse septa, and intracellular membranous organelles (mesosomes) appeared within.

\section{INTRODUCTION}

A previous report (Kusaka, 1967) indicated that protoplasts of Bacillus megaterium grew well and divided in I \% casein hydrolysate (enzymic) medium containing $0.5 \mathrm{M}-$ $\mathrm{NaCl}$ as the stabilizer, and a part of the murein which was known to be completely lost in protoplast formation was formed on the cytoplasmic membrane during growth. When murein formation was disturbed by penicillin, division of protoplasts was completely inhibited. These facts suggested that formation of murein around the protoplasts might have been essential for their division. To obtain more detailed information about the changes in the surface structures of protoplasts during division and growth, the fine structure of the protoplasts has been examined by electron microscopy.

\section{METHODS}

Organism and culture conditions. Bacillus megaterium IAM I I 66 was used throughout the study. Media, methods for formation of protoplasts and growth conditions were as described earlier (Kusaka, 1967).

Electron microscopy. Cells were harvested by centrifugation and suspended in $0.5 \mathrm{M}-$ $\mathrm{NaCl}$ in $\mathrm{O} . \mathrm{I}$ M-phosphate buffer ( $\mathrm{pH} 6.5$ ) containing $1 \% \mathrm{OsO}_{4}(\mathrm{Merck})$ and kept at $4^{\circ}$ for $\mathrm{I} 5 \mathrm{~h}$. After fixation, cells were washed several times with $50 \%$ ethanol by gentle decantation and stained with saturated uranyl acetate in $50 \%$ ethanol at $4^{\circ}$ for $2 \mathrm{~h}$. The pellets were then dehydrated in a graded series of ethanols, transferred to acetone and embedded in an Epon 812 mixture (Shell Chemical Co.). Sections were cut on a Porter-Blum MT-2 ultramicrotome (Ivan-Sorvall Co.) with a glass knife, picked upon 
formvar-coated grids reinforced with carbon, stained with uranyl acetate and lead citrate (Frasca \& Parks, 1965) and examined with a JEOL JEM-7A electron microscope operating at $80 \mathrm{kV}$.

\section{RESULTS}

Initial protoplasts were almost completely free from cell wall and about $\mathrm{I} \cdot 6 \mu \mathrm{m}$. in diameter. Small fibrous strands were attached to the surface of the cell, being perhaps remnants of cell-wall materials (Pl. I, fig. I). After $2 \mathrm{~h}$. growth, the cell enlarged about 2.5 times in diameter and a coat-like material appeared all around the cell surface to form the outermost layer. A protuberance appeared on the coated protoplasts (P1. I, fig. 2) and enlarged during a further I h. of growth (Pl. I, fig. $3 a, b$ ). until a symmetrical dumbbell-shaped body had formed (Pl. 2, fig. 4). In dividing cells, the coat did not form over the protuberance, so after division two kinds of daughter cells-one with and one without a coat-appeared. The coat was loosely packed and consisted of fibrous material (Pl. 2, fig. 5). The large nuclear region, containing sparse filaments, can be seen in the growing protoplasts (Pl. I, fig. $3 b$ and Pl. 2, fig. 5).

Protoplasts in the presence of penicillin. In the presence of penicillin (1000 units $/ \mathrm{ml}$.) division was suppressed but the cells enlarged to about $6 \mu \mathrm{m}$. in diameter. Thin sections of these cells d emonstrated that the coat did not develop around the protoplasts but fibrous strands which might otherwise have formed the coat were released into the medium (Pl. 2, fig. 6).

Cells after $12 \mathrm{~h}$. of growth in the absence of penicillin. After about $12 \mathrm{~h}$. of growth in the absence of penicillin, cell-wall formation was complete, and normal-looking, compact cell walls about $60 \mathrm{~nm}$. thick were formed. These walls appeared to have two components, an inner, uniform layer and an outer, granular or fibrous layer, similar to the coat observed on protoplasts after a few hours growth. The cells were still spherical, and never revert to normal rods. Within these cells, several septa formed simultaneously, and intracellular membranous structures (mesosomes) were observed (Pl. 3, fig. 7, 8).

\section{DISCUSSION}

It was previously shown Kusaka (1967) that protoplasts of Bacillus megaterium grew well and divided in casein hydrolysate medium containing $0.5 \mathrm{M}-\mathrm{NaCl}$ as the stabilizer. The sequence of growth and division was similar to the results reported by McQuillen (1955). During the multiplication of protoplasts, the formation of cell wall was resumed and a part of the wall appeared to be formed on the protoplasts. When wall formation was prevented by penicillin, division was prevented although growth was not influenced. Observations presented in this paper revealed that the fibrous coat was formed around growing and dividing protoplasts. The coat did not develop in the presence of penicillin. Under these circumstances fibrous materials, which might otherwise have formed the coat, appeared to be released into the medium. These results indicate that the coat may have represented the new wall (murein) and that wall formation may have resumed during protoplast growth. They also indicate that the fibrous materials which were released into the medium may have represented unorganized murein synthesized in the presence of penicillin, since penicillin is known to prevent the cross-linking reaction in the synthesis of bacterial murein (Wise \& Park, 
Journal of General Microbiology, Vol. 63, No. 2

Plate I
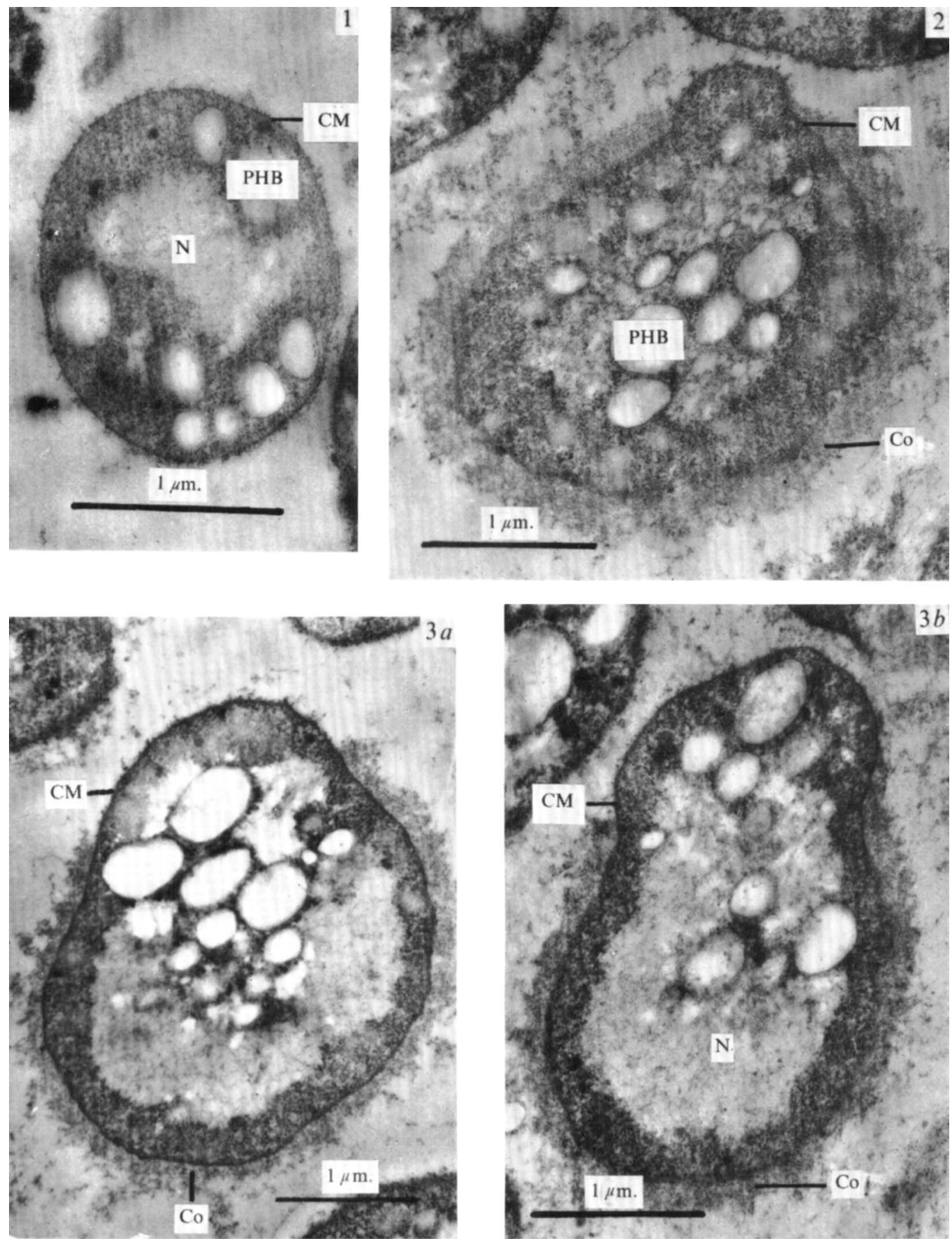

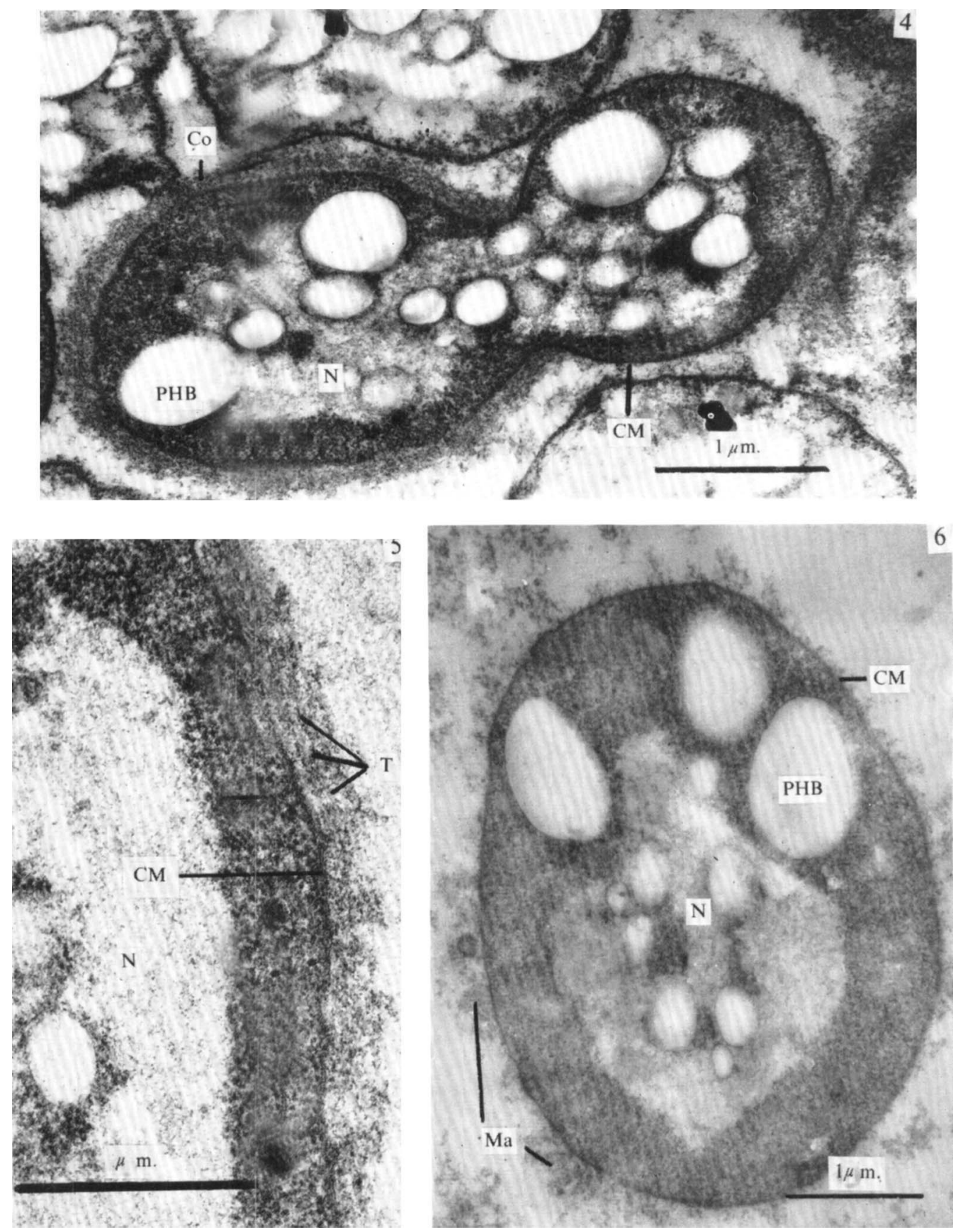

I. KUSAKA 
Journal of General Microbiology, Vol. 63, No. 2

Plate 3
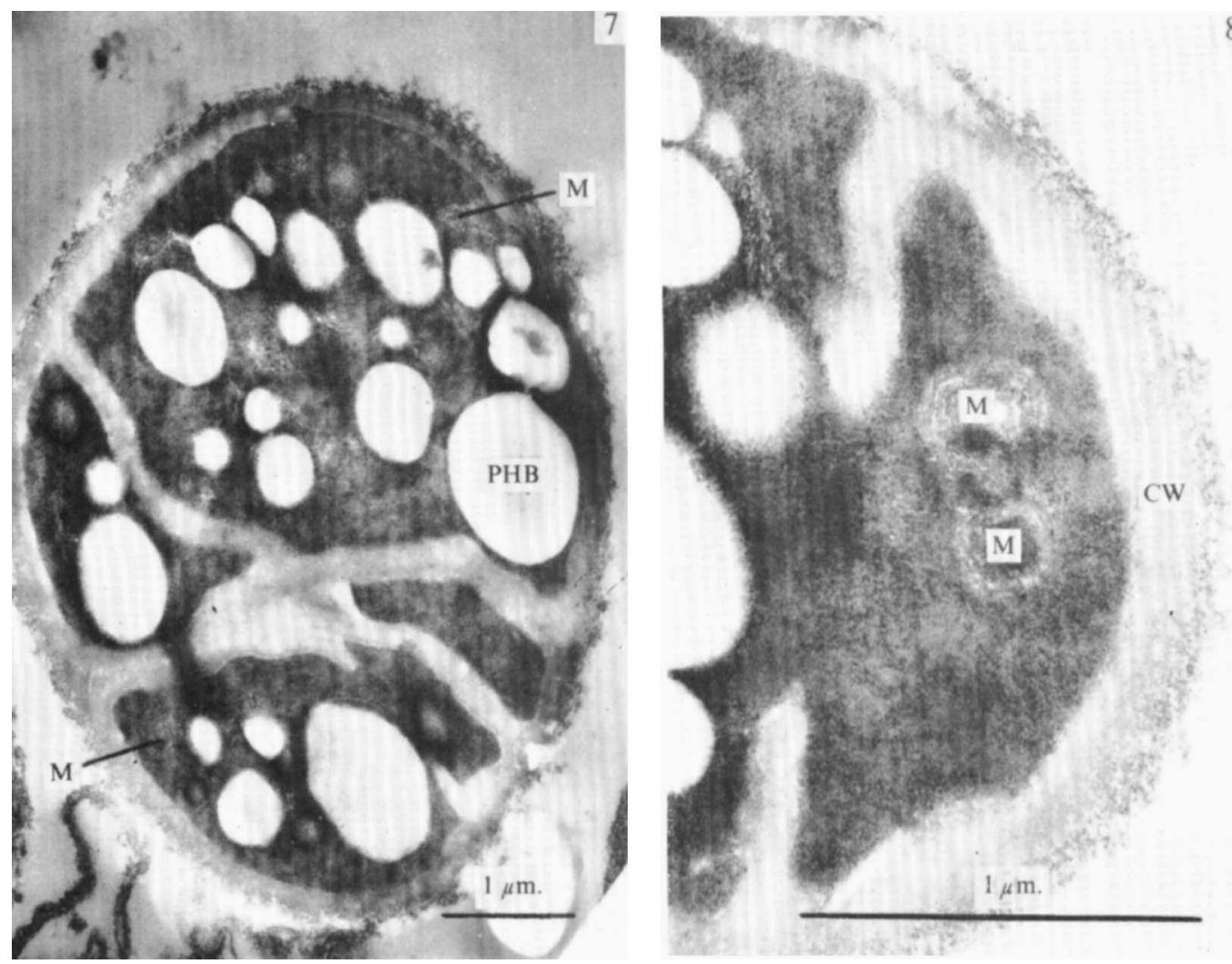
1965). In dividing protoplasts the protuberant area lacked a coat and may have been extruded from the 'parent' which was still surrounded by one.

After about $12 \mathrm{~h}$. growth in the absence of penicillin, wall formation by protoplasts was complete, a thick compact cell wall having been formed. A number of septa were then formed simultaneously, one cell dividing into 4 to 6 although reversion to a normal rod was never found. Recently, Landman, Ryter \& Fréhel (I968) reported that protoplasts of Bacillus subtilus reverted to bacillary form when grown in gelatin media. In their study the reverting cells possessed a wide array of shapes, including branched and very irregular ones. These irregular forms, especially branched cells, might easily have led to rod-shaped cells. In liquid culture, as used here, cells were only spherical. These differences in morphology might be caused by the difference in the physical milieu surrounding the cell.

Mesosomes, which are expelled from the cells during protoplast formation (FitzJames, 1964), were found in cells grown for $12 \mathrm{~h}$. but their participation in septum formation was not observed. However, the strain used in the study contained poly- $\beta$ hydroxybutyrate granules which interfered with exact observations of the mesosomes. Mesosomes appeared to develop after normal cell walls were formed.

\section{REFERENCES}

FITZ-JAMES, P. (1964). Fate of mesosomes of Bacillus megaterium during protoplasting. Journal of Bacteriology 87, I483-I49I.

Frasca, J. M. \& Parks, V. R. (1965). A routine technique for double staining ultra thin sections using uranyl and lead salts. Journal of Cell Biology 25, I57-I6I.

KUSAKA, I. (1967). Growth and division of protoplast of Bacillus megaterium and inhibition of division by penicillin. Journal of Bacteriology 94, 884-888.

LANDMAN, O. E., RYTER, A. \& FréHel, C. (1968). Gelatin-induced reversion of protoplasts of Bacillus subtilis to the bacillary form: electron microsco pic and physical study. Journal of Bacteriology 96, $2154-2170$.

MCQUILlEN, K. (1955). Bacterial protoplasts: growth and division of Bacillus megaterium. Biochimica

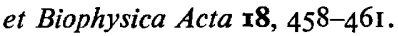

Wise, E. M., \& Park, J. T. (1965). Penicillin: its basic site of action as an inhibitor of a peptide cross-linking reaction in cell-wall mucopeptide synthesis. Proceedings of the National Academy of Sciences of the United States of America 54, 75-81.

\section{EXPLANATION OF PLATES}

$\mathrm{CM}$, cytoplasmic membrane; $\mathrm{PHB}$, poly- $\beta$-hydroxybutyrate granules; $\mathrm{N}$, nuclear region; Co, coat; $\mathrm{Ma}$, materials; $\mathrm{M}$, mesosome; $\mathrm{CW}$, cell wall.

\section{Plate I}

Fig. I. Initial protoplast of Bacillus megaterium. $\times 30,000$.

Fig. 2. Budding protoplast of $B$. megaterium showing a small protuberance breaking through the coat $(\mathrm{Co}) . \times 25,000$.

Fig. $3(a, b)$. Dividing protoplasts of $B$. megaterium showing a growing protuberance. Coat does not form on the protuberance. $(a), \times 20,000 ;(b), \times 25,000$.

\section{Plate 2}

Fig. 4. Dumbbell-shaped protoplast of Bacillus megaterium. $\times 25,000$.

Fig. 5. Organized fibrous materials in the coat $(T)$ formed around the protoplast. $\times 70,000$. 
Fig. 6. Protoplast of $B$. megaterium grown in the presence of penicillin. The materials which might be the coat material appear to be secreted into the medium. $\times 20,000$.

\section{Plate 3}

Fig. 7. Multiseptate cell of Bacillus megaterium. $\times$ I5,000.

Fig. 8. Multiseptate cell of B. megaterium showing a typical mesosome $\times 45,000$. 